\title{
Examination of Teacher Identities of Pre-service Teachers Within the Scope of Teaching Practice ${ }^{1}$
}

\section{Hatice Çilsalar Sagnak ${ }^{2} \quad$ Gökçe Sancak Aydın ${ }^{3}$}

\section{Type/Tür:}

Research/Araştırma

Received/Geliş Tarihi: July 4/ 4

Temmuz 2020

Accepted/Kabul Tarihi:

November 13/ 13 Kasim 2020

Page numbers/Sayfa No: 762-780

Corresponding

Author/İletişimden Sorumlu

Yazar: hatice.cilsalar@yobu.edu.tr

\section{$\checkmark$ iThenticate}

This paper was checked for plagiarism using iThenticate during the preview process and before publication. / Bu çalışma ön inceleme sürecinde ve yayımlanmadan önce iThenticate yazılımı ile taranmıştır.

Copyright @ 2017 by

Cumhuriyet University, Faculty of Education. All rights reserved.

\section{Abstract}

Pre-service teachers experience various theoretical and practical learning experiences while preparing for the teaching profession. Pre-service teachers have the opportunity to experience education and training in real practice environments with the teaching practices they participate in. In this study, it was aimed to examine the professional identity perceptions of pre-service teachers within the scope of their professional teaching practice in which pre-service teachers experience teaching in the context of teaching practice which are the practices contributing to their professional development. In this study, which was designed as phenomenological design, which is qualitative research, 30 pre-service teachers who took the teaching practices course were selected with the purposive sampling method. The data obtained from the interviews were analyzed. The participants' perceptions of who the teacher is and what the teacher does are emphasized. In this context, the teacher identities of the participants were discussed. The participants stated that there was a positive change in the development of teacher identity during teaching practice with the support of both the cooperating teachers and academic advisors. The participants emphasized the natural identity, and the importance of pedagogical knowledge. In addition, preservice teachers stated that they have experiences in all their sub-identities related to their professional identities and that they use all the information they have obtained in the education faculty at different points. Parallel to results, suggestions for practices and research that are thought to contribute to teacher education are presented in the study.

Keywords: Teacher identity, teaching practices, teacher education, preservice teacher, phenomenology

\section{Suggested APA Citation/Önerilen APA Atıf Biçimi:}

Çilsalar Sagnak, H., \& Sancak Aydın, G. (2021). Examination of teacher identities of pre-service teachers within the scope of teaching practice. Cumhuriyet International Journal of Education, 10(2), 762780. http://dx.doi.org/10.30703/cije.763758

\footnotetext{
1 'Bu çalışma, 2018 yılında Society for Information Technology \& Teacher Education (SITE) (March 26-30) konferansında 'An investigation of change on career decision and professional identity of pre-service teachers during teaching practice' isimle sunulan çalışmanın öğretmen kimliğine odaklanan kısmının detaylandırılış halidir.
}

2 Dr. Öğr. Üyesi, Yozgat Bozok Universitesi, Eğitim Fakültesi, Eğitim Programları ve Öğretimi Bölümü, Yozgat/Türkiye Asst. Prof. Dr., Yozgat Bozok University, Faculty of Education, Department of Curriculum and Instruction, Yozgat/Turkey e-mail: haticecilsalar@gmail.com ORCID ID: orcid.org/0000-0002-6282-2152

${ }^{3}$ Dr. Öğr. Üyesi, Yozgat Bozok Universitesi, Eğitim Fakültesi, Rehberlik ve Psikolojik Danışmanlık Bölümü, Yozgat/Türkiye Asst. Prof. Dr., Yozgat Bozok University, Faculty of Education, Department of Guidance and Psychological, Yozgat/Turkey e-mail: sancakag@gmail.com ORCID ID: orcid.org/0000-0003-1305-1221 


\title{
Öğretmenlik Uygulaması Kapsamında Öğretmen Adaylarının Öğretmen Kimliklerinin İncelenmesi
}

\begin{abstract}
Öğretmen adayları, öğretmenlik mesleğine hazırlanırken teorik ve uygulamaya yönelik çeşitli öğrenme deneyimleri yaşamaktadır. Bu kapsamda hizmet öncesi eğitimleri sürecinde, katıldıkları öğretmenlik uygulamaları ile eğitim-öğretimi gerçek uygulama ortamlarında deneyimleme fırsatı bulmaktadırlar. Bu çalışmada, öğretmen adaylarının öğretimi deneyimleme sürecinde profesyonel olarak mesleki gelişimlerinin yönelik yürütülen öğretmenlik uygulamalarının kapsamında araştıma ile, öğretmen adaylarının profesyonel öğretmenlik deneyimi ve uygulamaları kapsamında mesleki kimlik algılarının incelenmesi amaçlanmıştır. Nitel araştırma türlerinden olan fenomonolojik desen yardımıyla tasarlanan bu çalışmada, amaçlı örnekleme yöntemiyle öğretmenlik uygulamaları dersi alan 30 öğretmen adayı, çalışmanın katılımcıları olarak belirlenmiştir. Katılımcıların görüş ve algılarını incelemek amacıyla yapılan görüşmelerden elde edilen veriler analiz edilmiştir. Hizmet öncesi öğretmen adaylarının öğretmen kimliklerine dair algıları incelenirken özellikle öğretmenin kim olduğu ve ne yaptığına dair algılar üzerinde durulmuştur. Çalışmada, katılımcılar öğretmenlik uygulaması kapsamında hem uygulama öğretmeni hem de akademik danışmalarının desteği ile öğretmen kimliğinin gelişiminde olumlu yönde değişim olduğunu belirtmişlerdir. Katılımcıların profesyonel öğretmenlik kimlikleri arasında yer alan alt kimliklerinden biri olan doğal kimliği ve sahip oldukları bilgilerden biri olan pedagojik bilginin önemini vurguladıkları görülmüştür. Ayrıca öğretmen adayları profesyonel kimlikleri ile ilgili bütün alt kimliklerine yönelik deneyimlere sahip olduklarını ve eğitim fakültesinde edindikleri bütün bilgileri farklı noktalarda kullandıklarını belirtmişlerdir. Araştırmadan elde edilen bulgular doğrultusunda öğretmen eğitimine katkı sunacağı düşünülen uygulamalara ve araştırmalara yönelik öneriler çalışmada sunulmuştur.
\end{abstract}

Anahtar Kelimeler: Öğretmen kimliği, öğretmenlik uygulaması, öğretmen eğitimi, öğretmen adayı, fenomenoloji.

\section{Introduction}

Teaching practice during pre-service teacher education plays an important role in preservice teachers' professional life by giving insights on how to teach in their future classrooms. In addition to its functional role, teacher identity includes a personal aspect of the teaching profession covering both "one identifies with being a teacher and how one feels as a teacher."(Mayer, 1999, pp. 6-7), which emphasizes the emotional dimension of the profession. Specifically, beliefs toward how to teach and behave as a teacher are shaped during the teacher education programs. From the first day in the program, building a solid ground of teacher identity is one of the most important factors affecting pre-service teachers' roles in their classrooms. Education faculties offer pre-service teachers opportunities for shaping their teacher identities by both theoretical and practical courses in the programs.

Teacher identity can be defined as "being recognized as a certain 'kind of person'; identity is connected not to internal states but to performances in society. It is also 'an important analytical tool for understanding schools and society'" (Gee, 2000, p. 99). As a teacher identity study, Kelchtermans (2009) has provided a different view on the professional identity of teachers. "Because of a static relationship of the self that implicitly disregards or rejects its dynamic and biographical nature" (p. 261), Kelchtermans opposes the use of the term identity which highlights teacher development as a process. Instead, the term self-understanding that recognizes the self 
at any time or any space is the true product of a lifelong process was proposed by Kelchtermans (2009). Besides, it is far away from the existentialist view which refers to the identity at the center and deeper point of the self. Although identity is referred to as understanding of the self, the reality that identities of individuals are not independent of time and space can be missed out from time to time. This refers to the identity formation process stretches through the lifetime of an individual. The change of pre-service teacher's identity was examined in line with the opinion of Kelchtermans (2009) and based on the evaluation of the essence and development in the teaching career.

Walkington (2005) specifies the connection between teacher identity and teaching approach as "the uniqueness of every teacher's approach to teaching, shaped by personal teacher identity, what makes every classroom 'look' different"(p. 54). Therefore, practices before being a teacher of a class create learning opportunities to shape pre-service teachers' teaching philosophies and modes of their teaching practices. These practices are mostly directed by functional teacher roles of cooperating teachers and directions of university supervisors. Under the guidance of these key role models, values, and beliefs of the pre-service teacher are also active in the role of formalization of their teaching performances. As the personal side of the teaching profession, teacher identity is mostly originated from these beliefs and values.

To make sense of teacher identity, the studies examining individuals' perceptions of identity point out that identity is dynamic (Rodgers and Scott, 2008; Van Veen and Sleegers, 2006; Zembylas, 2003). The identity changes by having teaching experience and progresses in the profession (Beauchamp and Thomas, 2006; Thomas and Beauchamp, 2007). In addition to these, it is affected by external and internal factors. Internal factors are constructed by individuals' characteristics such as personality while external factors comprise life experience, work experience, gender, ethnicity, and religion (Flores and Day, 2006; Rodgers and Scott, 2008; Sachs, 2005). Beijaard, Meijer, and Verloop (2004, p.122-123) portrayed four main features of teachers' professional identity. (1)The formation of teacher identity is an 'ongoing process' such as a spiral of analysis and reanalysis of their experiences. (2)Professional identity gets pieces from both person and context. Teachers' behaviors are shaped by their professional characteristics, knowledge, attitude, and their working circumstances, etc. (3)Sub-identities of professional identity; which are related contexts, relations, knowledge, etc.; comprise teachers' overall identity. These could be in harmony or inconsistency and may have a major formation role or may be incidental. (4)Being active in the professional process results in the development of the teacher identity which is identified as an important element called 'agency'. Analysis of teacher identity, which is composed of different dimensions and influenced by different factors, can contribute to the development of teaching perception and teaching. Moreover, the identity studies may lead to both teacher trainers and candidate teachers guiding on conceptualizing and a better understanding of the support that teacher candidates and first-year teachers need (Volkmann and Anderson, 1998).

It is thought that the professional identities of the pre-service teachers are shaped by their professional perceptions constructed during their pre-service education (Korthagen, 2004). These perceptions can also be influenced by their 
previous learning experiences from kindergarten to university and the teaching experiences of their previous teachers (Baran, Cilsalar, and Mesutoğlu, 2017). Their professional identity continues to change and develop during teacher education and the early stages of their teaching (Zembylas, 2005).

Besides teaching practice, teacher identity affects both professional development and attitudes towards changes in education (Beijaard, Meijer and Verloop, 2004). Teacher education which is an intentional formation process of teacher identity is the deliberate part of it. It is critical because pre-service teachers can create or develop their views on the features, duties, and responsibilities of the teacher during the program intensively. Once teacher educators understand the perspectives of their students towards teaching and learning, they can enable the students -pre-service teachers- to plan their future teaching-learning activities to have effective meaningmaking and decision-making processes.

Teacher identity development is a process that includes continuous change (Lamote and Engels, 2010), covers the first years of teaching, and highlights the importance of teachers' professional development. Olsen (2008) states that examining teacher identity may provide a framework to examine teaching practices. Monitoring and examining the professional identities of trainee teachers in the practice processes can be an important step both in shaping their future teaching activities and increasing the effectiveness of pre-service teacher education programs (Beauchamp and Thomas, 2009). It is expected that teacher identity analysis supports the development of selfunderstanding of pre-service teachers.

It is noteworthy that the number of studies, carried out in Turkey, examining teacher identity is relatively limited (Duru, 2006; Yasar, Karabay and Bilaloğlu, 2013). Since teacher identity analysis is very important in the process of preparing the students for the profession, more studies are needed in that research field. Because of the more detailed explanation of pre-service teachers' identity, the more insights would be helpful to revise pre-service and in-service education programs to enlighten their views toward teaching. The results of this study are expected to provide useful information to help educators to understand the relationship between pre-service teachers' teaching experiences and their identity formation. The findings, also, could contribute to in-service trainers as well as pre-service teachers and teacher training institutions both in Turkey and abroad. It can enable the enlargement of understanding their identity formation process during higher education and their professional development.

To understand pre-service teachers' views on teachers' features, responsibilities, and duties, there are two different frameworks. Firstly, Gee (2000) conducted a comprehensive study that examines the literature to create a framework for teacher identity, which can be used for different professions and can guide identity studies. According to this framework, professionals have four types of identities that answer the question 'Who is a teacher?': natural-identity, institutional-identity, discourse-identity, and affinity-identity. 
Table 1

Gee's Identity Categories

\begin{tabular}{ll}
\hline \multicolumn{1}{c}{ Category } & Formation Process \\
\hline Natural- & A professional presents his/her biological features, at first glance. This \\
identity & $\begin{array}{l}\text { identity is comprised of these biological factors like a person's "natural" } \\
\text { characteristics (gender, appearance, etc.) and states in which one is } \\
\text { naturally present and neither he/she nor the society can control it. Like } \\
\text { being a twin. }\end{array}$ \\
$\begin{array}{l}\text { Institutional- } \\
\text { identity }\end{array}$ & $\begin{array}{l}\text { A personal view is comprised of both the positive and negative situations } \\
\text { in the organization. The identity is assigned by the authority to the person } \\
\text { through laws, rules, regulations, principles, etc. Like being a teacher or a }\end{array}$ \\
principal at a school. \\
identity & $\begin{array}{l}\text { The view is created by the people around the person about the success, } \\
\text { failure, and characteristics of herself or himself. The identity is composed } \\
\text { of other people's perspectives and created by others for the person } \\
\text { (charismatic, active, passive, etc.). }\end{array}$ \\
Affinity- & $\begin{array}{l}\text { The view of the groups in which individuals share their interests or } \\
\text { identity }\end{array}$ \\
experiences in common. The identity is shaped by the characteristic \\
experiences that the person possesses and shares with a particular group, \\
whose purpose is to be part of the group and to ensure the continuity of \\
the group (The identity acquired in the group of field specialist teachers, \\
etc.).
\end{tabular}

Secondly, the answer to the question "What does a teacher do?" can be revealed by the framework developed by Beijjard, Meijer, and Verloop in 2004. This framework points to three important components in teachers' identity development process. The components state that the teacher's knowledge of the field-content knowledge (1) and pedagogical knowledge and the ways of using this information (2) reflected a significant part of their identity. In addition to these, it is also drawn attention to didactic experiences (3) which express teachers' thoughts about their ability to make changes in both content and pedagogical knowledge according to ever-changing environmental conditions. Since these components are shaped by both personal and contextual circumstances, they enable the development of teacher identity when they come together.

With this study, it is intended to give insights to the revision of pre-service teacher education programs and contribute to their personal and professional development by increasing the self-awareness of pre-service teachers during their teaching practice and classroom observation courses in pre-service teacher education. Furthermore, in the process which affects the organization of learning environments and their tendency to innovations and reforms (Canrinus, Helms-Lorenz, Beijaard, Buitink and Hofman, 2012), they can get more benefit from teaching practice with the determination of professional competence perceptions. This study aims to achieve; (1) increasing self-awareness of pre-service teachers within the scope of teaching practices, (2) examining the formation process of teacher identities of pre-service teachers, and (3) providing more comprehensive preparation for the teaching profession, consequently. The overall aim of the study is to explain teacher identity perceptions of pre-service teachers by concentrating on how they shape and reform 
their professional identity during their first teaching practice in real classrooms. The research question of the study:

How do pre-service teachers shape their perceptions of professional identity within the scope of their first teaching practices?

a) How do pre-service teachers perceive who a teacher is within the scope of teaching practices?

b) How do pre-service teachers perceive what a teacher does within the scope of teaching practices?

\section{Method}

\section{Research Design}

In the study; phenomenological research, one of the qualitative research methods, was performed to examine the professional identity development of pre-service teachers. Phenomenological studies aim to explain the facts that are known by everyone but cannot be explained in depth (Yıldırım and Şimşek, 2008). Furthermore, since the aim of such research is to determine the experiences and/or perceptions related to the phenomena (Creswell, 2009), teacher identity has been identified as the center of the research. This study focused on an in-depth analysis of the participants' thoughts and perceptions about their professional identity. Within the scope of this research, it was tried to clarify the identity formation process and the perceptions of pre-service teachers on this process by their reports about them.

\section{Participants}

The participants of this study were 30 pre-service teachers who continued their undergraduate education at a state university located in the region of Turkey. They were selected among the volunteers on the basis of the easily purposive sampling method among the students who went to public schools as pre-service teachers for the first time. In this study, 19 (63.3\%) of the participants were female and $11(36.7 \%)$ were male, while the mean of their age was 21.8, between 20 and $34(s d=4.41)$. All the participants visited the classrooms as pre-service teachers for the first time as a requirement of their program. The course content in application in terms of teaching was the same for all participants.

This teaching practice aims to support pre-service teachers to teach in real teaching environments under the guidance of a cooperating teacher and a university supervisor at the faculty of education. Each pre-service teacher has to participate in teaching practice for at least two semesters during their pre-service education. All the participants visit different levels of the public schools for 6-hour in a week for 14 weeks. After obtaining the approval of the university supervisor, they apply the lesson plans that they prepared with the guidance of the cooperating teacher in the classroom. At the end of the semester, they present reports on the practices' purpose, flow, and evaluation, and their opinions toward the practices.

\section{Data Collection Tool}

Qualitative data were collected to enable them to conduct their self-assessments throughout the process via interviews. For this purpose, the interview form was developed by the researchers. The interview form included items related to 
demographic information and teacher identity. The demographic information form included items related to gender, age, department and teacher training program, familiarity with teaching, and previous informal or formal teaching experiences and perceptions on the teaching profession. For example; "What kind of teaching experiences did you have as an individual before you participated in teaching practices?" and "Who was the teacher that you can define as the best and effective teacher trained you so far?", "What were the features that made her/him the best and most effective for you?".

Regarding teacher identity, the questions, which were categorized as the perspective of pre-implementation teaching and the development of identity during teaching practice, were given to pre-service teachers within the framework of the defined teacher identity framework of Gee (2000). For example; "If you summarize what have you done during the practice in general, what are the most important thing(s) you have in your mind as a future teacher? Why is that? How did this/these make you feel as a teacher?".

In the process of constructing the interview protocol, sample questions were selected after a comprehensive literature review and presented to the field experts. Before the implementation of the interview, the protocol was examined by two different experts from the educational sciences department. Considering the suggestions of the experts, it was revised and piloted with three pre-service teachers who are not the participants of the study but participating in teaching practice in the same semester. After the pilot study, minor arrangements were made to increase the comprehensibility of the form in line with the feedback received from the participants, and the form was finalized. The interview protocol was designed to analyze teacher identity in two categories concentrating on 'who is a teacher?' and 'what does a teacher do?'. The interview questions were categorized by following the framework categories of Gee (2000) and Beijjard, Meijer, and Verloop (2004). The interview was conducted at the end of the semester.

\section{Data Collection and Analysis}

During data collection, the participants were interviewed at the end of the semester about their teacher identity and their views on the teaching profession. A detailed codebook was presented in Table 2 . The data were analyzed using selective coding, which is one of the qualitative data analysis methods. The data were analyzed by using the descriptive analysis method with the pre-prepared codebook for this study. The codebook contained the code name, description of the code, keywords, and code examples from the data. In the findings part of the study, the frequencies for each code were given to indicate how intensively the participants referred to each code during the interviews. Thus, interpretations on codes were emphasized and focused in addition to the frequencies.

For the reliability of the data during the data analysis process, the researchers tried to determine the intercoder reliability by coding the data from three different participants who were selected randomly. The intercoder reliability was calculated as $92.94 \%$ by comparing the codes of two different coders. Neuendorf (2002), who analyzed the criterion for reliability, stated the perfect fit as $90 \%$ and above. For this reason, the value showed the reliability of the analysis process. 
Table 2

Codebook For Qualitative Data Analysis

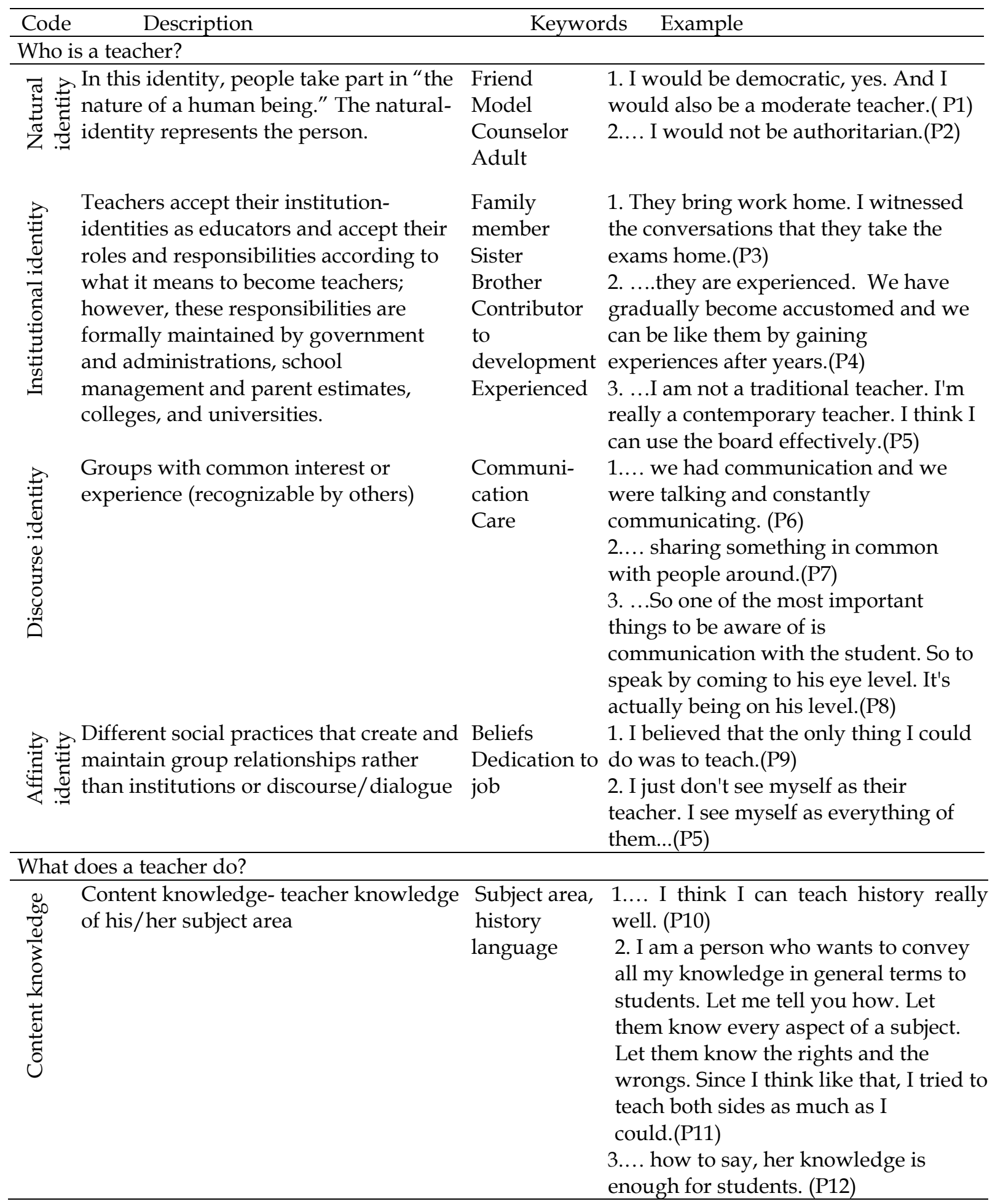




\begin{tabular}{|c|c|c|c|}
\hline 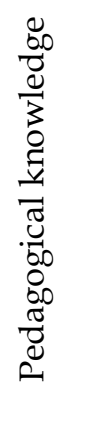 & $\begin{array}{l}\text { As a pedagogical expert, someone who } \\
\text { has a good balance between the } \\
\text { pedagogical side as well as the didactic } \\
\text { side. General awareness of students' } \\
\text { needs, the sources of information they } \\
\text { bring to the lesson, the personal } \\
\text { situations or problems that students } \\
\text { may have, as well as the broader social } \\
\text { problems and challenges that affect } \\
\text { learning and teaching }\end{array}$ & $\begin{array}{l}\text { Teaching } \\
\text { activity } \\
\text { design } \\
\text { Extracurricul } \\
\text { ar activities } \\
\text { Chess }\end{array}$ & $\begin{array}{l}\text { 1. Following students up and make } \\
\text { the lesson fun...(P13) } \\
2 . \text { In the class, the teacher made } \\
\text { everyone move freely, and he } \\
\text { motivated them by saying they can do } \\
\text { whatever they want.(P13) }\end{array}$ \\
\hline 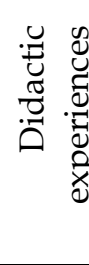 & $\begin{array}{l}\text { Teachers' ability to decide what works } \\
\text { and what does not work in the } \\
\text { classroom, which is important not only } \\
\text { in the development of pedagogical skills } \\
\text { but also in content knowledge }\end{array}$ & $\begin{array}{l}\text { Course re- } \\
\text { organization } \\
\text { Reconstructi } \\
\text { ons of } \\
\text { activities }\end{array}$ & $\begin{array}{l}\text { 1. During the teaching practice, the } \\
\text { activities that we do may not be } \\
\text { appropriate to the students' } \\
\text { development, also we may not be able } \\
\text { to pay attention to everything while } \\
\text { organizing our activities.(P18) }\end{array}$ \\
\hline
\end{tabular}
education, 25(1), 99-125.

\section{Results}

The results of the study are given in three parts as demographic characteristics of the participants, the pre-service teachers' answers to "Who is a teacher?" and "What does a teacher do?". While $61.5 \%$ of the participants described their primary school teachers as their best and most effective teachers, 30.8\% of them stated that it was their high school teachers, and $7.7 \%$ indicated their university teachers. In the definition of their influential teachers, the majority of the participants were impressed by their teachers who cared for them and were interested in even their smallest problems.

Almost all the pre-service teachers stated that they did not participate in any formal teaching practice, or they did not work in an institution as a teacher before the teaching practice in undergraduate education. Only one participant who had participated in school observation for two weeks during her secondary education had previous teaching experience of only classroom observation. Most of the participants who did not have this formal teaching experience $(n=18)$ stated that they were teaching informally to their siblings, cousins, children of neighbors, or friends. The other preservice teachers $(n=11)$ stated that they had the first experiences in this practice course. Then the teacher identities of the pre-service teachers were tried to be understood. The number of frequencies of the identities is given in Table 3.

Table 3

The Frequencies of Codes In Teacher Identity

\begin{tabular}{ll}
\hline Code & $f$ \\
\hline Who is a teacher? & \\
\hline Natural-identity & 62 \\
Institution-identity & 45 \\
Discourse-identity & 39 \\
Affinity -identity & 25 \\
\hline What does a teacher do? & 31 \\
\hline Field Information & 87 \\
Pedagogical Information & 19 \\
Didactical Experiences & \\
\hline
\end{tabular}




\section{Who is a teacher?}

Pre-service teachers' professional identity development during teaching practice was analyzed. According to the results of the study, Figure 1 was created to represent the changes in teacher identity of pre-service teachers.

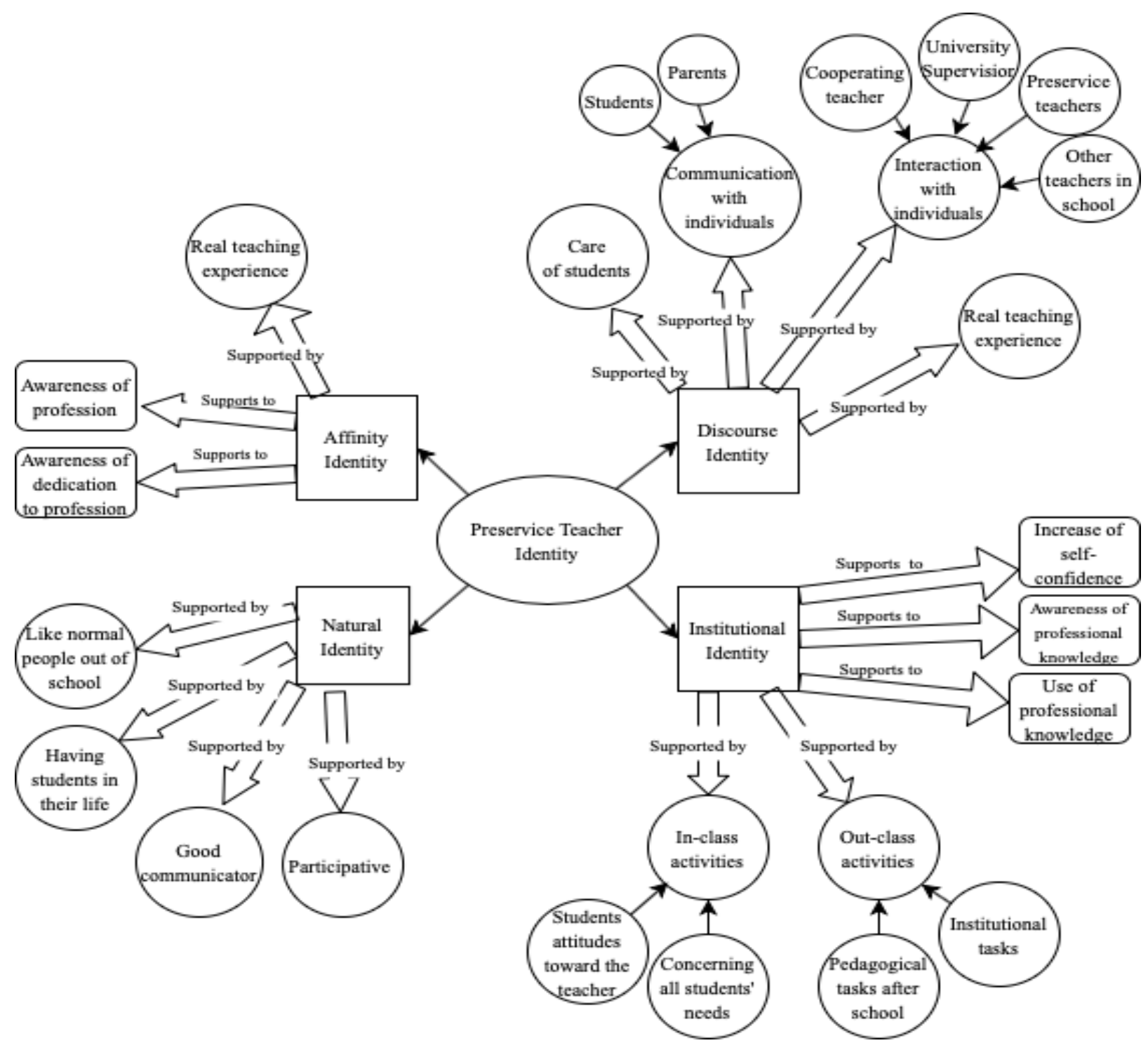

Figure 1. Teacher identity formation of pre-service teachers

Natural-identity. All of the participants emphasized the natural identity among other sub-identities. Within the scope of natural identity, pre-service teachers talked about some personal characteristics related to their professional life. They indicated that they prefer a soft teacher rather than a harsh one, for example, "I would be a soft teacher. I would not be a very harsh teacher."(P1).

In one of the interviews, the participant stated that "I tried to behave maturely. Thus, I felt more like a teacher." (P4) and she emphasized the change in her behavior. She also stated that she felt her teacher identity while behaving like an adult. Another example is the effect of pre-service teachers' innate interpersonal communication skills. "My sincere attitude made them happy to come and approach me."(P1). She 
pointed out that the way they communicate with students as a teacher had a positive effect on their relations with the students and also contributed to her vision as a professional.

The participants who listed the natural identity characteristics of the teachers emphasized the role of sharing and good communication with these sentences; "They should be good at communicating with their students... A teacher should know how to share."(P2). After the practice, one of the participants who did not have any previous teaching experience defined the teacher as "A teacher does not have enough time to spend with his/her family because of teaching responsibilities that they have to concern after school." (P3) and pointed out the change in her perceptions in this process. Also, they described that teachers are not different from other people in their daily life as "...I imagined teachers more different, but I realized that their standard life is like normal people by their talks at teachers' room in the breaks. They go to markets for shopping or visit friends after school like other people..."(P19). To sum up, the participants defined teachers as people who know how to share, communicate well, have a mature and mild manner, and have a standard life. They emphasized that teachers are human beings who have some biological and psychological characteristics.

Institutional-identity. It was observed that pre-service teachers frequently emphasized institutional identity $(f=45)$. They mostly talked about the activities they carried out in and out of classrooms as their experiences in corporate with identity. They emphasized the students' points of view from the elements constituting the teacher's institutional identity. It is highlighted the importance of the phrases in the teacher identity, for example; "I was very happy with the 'teacher' phrase." or "the first moment of a student said 'Teacher!' to me was the most remarkable moment of my professional life."(P19). It is seen that students' attitudes towards teachers during the course are effective in the formation process of their own teacher identity. For example, a participant said, "the way we lectured, their listening to us or the way they talked with us made me feel like a teacher."(P3). After their observations in the school, they emphasized that teaching is a profession that is not limited to school. For example, a participant shared that "They take work and exams to their home. We witnessed their work is not limited to school while observing teachers in this process." (P30).

It was observed that the opinions of pre-service teachers about the role of teachers were shaped in the classroom activities related to the institutional identity. One participant summarized as "The teacher doesn't just sit at the table and tell the students what they would do. But also, the teacher is interested in all things about the students"(P29). Within the scope of the teacher education program, pre-service teachers who have acquired theoretical knowledge have been able to obtain practical knowledge through teaching practice and have made use of their knowledge. With the teaching practice, they indicated that "I started to understand the professional teaching knowledge." (P17) and "I had experience and interacted with the professional knowledge in a better way than the theoretical one" (P22). Besides, it was revealed that all information obtained by the pre-service teachers shaped their own teacher identities by increasing their self-confidence. As an example, one participant stated: "After one of the lectures, we assessed with the students on how I taught. One of the students liked my lecture. I said okay. I really did something; I gave the knowledge to 
the students"(P4). Within the scope of the teaching experience carried out, pre-service teachers had the opportunity to experience the roles that teachers play in the institution.

Discourse-identity. During the practice, the pre-service teachers communicated with the cooperating teacher and other teachers working in the school. They closely interacted with other pre-service teachers in the practice group as well. For this reason, pre-service teachers who have the opportunity to form a discourse identity defined the small informal groups they formed for the development of this identity as "We were chatting, talking and constantly communicating" (P18). This may be due to the points of view of the people in the teaching profession that teachers should share professional things with the people around them. Thus, they pointed out that teachers could update themselves with the contribution of the people around them. To increase the effectiveness of this, the teacher should have good communication with the students, teachers, and parents. They emphasized that the teacher should take care of the students in that way, and they were supported by all teachers and other pre-service teachers in this process. They pointed out that this was one of the main sources for their teacher development.

Affinity-identity. As an affinity, pre-service teachers stated their perspectives on the teaching profession. One of the participants stated his affinity to the profession with the words "I believed that the only thing I could do was to teach." (P9). Moreover, as a result of their interaction with their students, they see themselves as real teachers and one of them stated that "I don't just see myself as their teacher. I see them as everything as if I were dedicated to them"(P29). With these sentences, it was emphasized that teaching is not only a profession but a process of dedication to students' development. With the practice, the pre-service teachers were aware of themselves as teachers with the support of their university supervisors and the interaction with the students at the school. One of the participants shared these words; "There was a lot of excitement, but after a while, we overcame it. We can become a teacher, and now I see myself as a teacher with this experience."(P17). All the participants stated that they started to see themselves as real teachers after this process.

\section{What does a teacher do?}

Pedagogical knowledge. The question of "What does a teacher do?" was answered in three different ways. Among these, the pedagogical knowledge of the teachers comes to the forefront. The practices on the realization of learning within the scope of pedagogical knowledge are quite remarkable for the participants. It can be clarified by the following quotations "Follow-up and entertainingly do the lesson"(P7), "It is the one that gives both information and can pass on that information to make it permanent today"(P10), "Whether it was the six-hat technique or the station technique we experienced in the faculty, they helped me a lot. Because students are having fun. They understand the lesson when they have fun"(P2). They felt that they were responsible for making the learning fun and active, and their satisfaction with the consequences of this way. One of the participants said "Our cooperating teacher mostly adhered to the book. When I become a teacher, I need to take my students on a journey by using maps and videos." (P2). Also, he mentioned his previous teacher "He did not give us any information in the course. He was reading. I am totally opposed to this."(P2). With these words, he talked about the difficulties of not using pedagogical 
knowledge effectively. However, the participants stated that the teacher needs to spend energy to provide classroom management to enhance students' learning. In fact, the teacher has important responsibilities in the classroom environment for the participants. They stated that the teacher has many responsibilities that require pedagogical knowledge use inside and outside the classroom.

Content knowledge. The participants indicated the influence of content knowledge on teacher identity development. Although the participants emphasized pedagogical knowledge, they were aware that learning is mostly realized through content knowledge. For example; "The teacher supports students' knowledge. It is the one that gives both information and can make it permanent"(P13). Correspondingly, another pre-service teacher from the history department indicated that "I should have more information; I should read more books."(P16). They tried to improve this knowledge with their curiosity in the field. They evaluated it by using the competence of the content knowledge while analyzing other teachers. For instance, a participant shared that "The content knowledge of the teacher that I observed was good, and he shared it with his students step by step" (P12).

Didactic experiences. Didactic experiences, which could be explained as teachers' experiences that they had to go out of the plan by arranging in-class and outof-class activities considering the current teaching and learning situations, are less examined by the participants. Within the scope of these experiences, the participants emphasized that teacher's relationships with the students should change according to the environment and situations. They underlined the requirement of organization of learning activities by paying attention to the individual differences because the students would need immediate help in solution of the problems. A participant stated that "We need to pay attention to the individual differences of children."(P14). Another one added, "We should adopt the teaching activities considering the development levels and interests of the children"(P2). These points represent the importance of teacher ability to adapt to teaching activities in the changing environment and context.

\section{Discussion}

This study concentrates on the explanation of pre-service teachers' teacher identity development during their first-time teaching practice in their undergraduate education. In the study, teacher identity development of 30 pre-service teachers who visited schools within the scope of teaching practice and completed a total of 112 hours for 14 weeks, 2 theoretical, 6 practical hours per week was reported.

A teacher's perception of teacher professional identity affects his or her ability to deal with problems both inside and outside the classroom (Beijaard et al., 2000). When the data were analyzed according to Gee's framework, pre-service teachers highlighted the natural identity. It has already been emphasized that teachers' interest in students, as well as their emotional and cognitive learning perceptions, lead to a positive change (Teven and McCroskey, 1997). It has been revealed that the participants' perceptions have changed with the increase in their interaction with students. Teacher identity also plays a role in creating positive emotional experiences in the teaching environment (Tsang and Jiang, 2018). This indicates a bi-directional process. In brief, when a trust-based relationship is established between teachers and their students, the identity of the teacher evolves. And the natural identity of the 
teachers based on a positive attitude provides a positive emotional environment in the teaching. Considering the findings of this study, the teacher was defined as nonauthoritarian, contemporary, able to communicate positively and effectively with his/her students. The characteristics as enthusiastic, guiding, accessible, positive, reliable, dedicated, collaborative, open to innovations, and having a sense of responsibility highlight that the teachers are "agents of change" in education (Van der Heijden, Geldens, Beijard and Popeijus, 2015). Teacher personality traits, that are mentioned by teacher trainees, actually point to the teacher who is the source and the director of the change. Goodson (1981, p. 69) points out the idea that teachers whose lives are constantly changing throughout their teaching career need to change beyond time, and teaching is directly related to the personal life of the teacher. The remarkable point among the findings of the research is that participants mentioned that teachers have a normal life like other people. There may have been a change in their perspectives on teaching as pre-service teachers had the opportunity to talk about teachers' professional and personal lives during the time they spent with them.

In terms of discourse identity, pre-service teachers put the communication with students to the forefront while they did not mention the communication with parents. The reason for this may be that pre-service teachers did not interact or rarely interacted with parents within the scope of teaching practices. However, pre-service teachers' experiences of communicating with parents could affect the success of their future students (Wills, 2018). Pre-service teachers who have the view that teaching can achieve its aim by a constant update and catching the age have found the opportunity to shape their professional identities within the scope of discourse identity. Continuous professional development throughout their careers is seen as a requirement for all teachers to capture change, review, and renew their knowledge, skills, and perspectives (Day, 2002). Therefore, the discourse based on being a teacher as a lifelong learner reveals the importance of discourse identity.

In terms of institutional identity, it is seen that pre-service teachers emphasize their activities in the classroom. Among these, their communication with the students as a teacher stands out as one of the key elements of teaching. Likewise, it is emphasized that the correct application of communication, which is among the characteristics of an effective teacher, not only from teacher to student but also from student to teacher is one of the effective teacher's markers (Stronge, 2018). In addition to communication, collaboration has emerged as a way of corporations. This practice process resulted in the embodiment of pre-service teachers' identities as self-confident teachers. Briefly, it was observed that how students perceive teachers was an important element of institutional identity and the positive feedback of the students supported the development of this identity. In addition, it is clear that pre-service teachers realized that teaching is not only limited to fulfill the requirements of their professional life, but also they have a life outside of school, and there is a change in their perspectives towards the teaching profession. Collaboration, which is necessary for change and development and affects both learnings of teachers and students, shapes the beliefs and attitudes of the teachers (Doppenberg, den Brok, and Bakx, 2012; Levine and Marcus, 2010).

In terms of affinity, it has been found out that teaching practices strengthen preservice teachers' perspectives and dedication to the profession. They are influenced by 
their teaching activities, their interaction with students, and the guidance of teachers in fulfilling the requirements of the profession in real school settings (Beauchamp and Thomas 2009). The high level of interaction with the students is quite effective in the improvement of their sense and understanding of the teaching profession.

When their answers to "What does a teacher do?" were examined within the scope of the aforementioned framework, the use of pedagogical knowledge was emphasized. Pedagogically, learning is fun, effective, and experience to realize the dynamics of the teaching process for the pre-service teachers. Also, classroom management that could support learning and motivation and increases interaction in the classroom (Schlee and Van Duzer, 2007) is one of the main focus of pre-service teachers. It was emphasized that the pedagogical knowledge applied in the classroom was the essence of teaching activities. Shulman (1986) also emphasizes that the application of the known teaching principles to some situations is related to the teacher's perception of the situation and that the knowledge-based practice may change according to the existing situation. It is pointed out that while the principles guide implementation, in some cases they are not identical.

In terms of content knowledge, pre-service teachers emphasized the place of content knowledge in pedagogical practices and pointed out that these two are inseparable. They stated that content knowledge should be constantly updated and transferred to the student. The point that draws attention is that they refer to pedagogy as content knowledge. At this point, pre-service teachers emphasize that pedagogy knowledge is among the most important requirements for a teacher. The studies revealed that pre-service teachers did not perform enough to apply the theoretical knowledge, they learned during their teacher education, in the classroom (Börger and Tillema, 1993). Although didactic experiences are important for taking precautions before they occur in the classroom and intervening immediately in case they occur (Börger and Tillema, 1993), pre-service teachers mentioned the didactic experiences quite limitedly. Having limited didactic experiences may have resulted from over control of their academic advisors on the planning process and the cooperating teacher on in-class practices and planning process. As a result, pre-service teachers found opportunities to develop and change their teacher identities within the scope of their teaching practices. In this study, it was found that mostly the center of pre-service teachers' identities is based on natural identity, and they frequently use their pedagogical knowledge.

\section{Concluding Remarks}

In light of the findings of this study, it is thought that it will be beneficial to develop more structured gains and awareness-raising practices within the scope of teaching practice courses. Considering the importance of the teaching experience in teacher identity, the courses based on experience can be augmented and the supervision process of pre-service teachers can be enriched in undergraduate education. To move this study forward, the teacher identity development of the pre-service teachers who are from different departments can be analyzed to reveal differences or similarities for those pre-service teachers. This study was concentrated on the pre-service teachers who had first-time teaching experience. For further studies, candidate teachers can be examined in their first year of experience. Another suggestion for further studies is 
that the number of participants can be enlarged with cooperating teachers and university advisors of the pre-service teachers to triangulate data and get views of outsiders on this personal process.

This study is limited to the pre-service teachers from the different departments. In further studies, more specifically the fields of pre-service teachers can be considered in terms of observing the change in teacher identity. Additionally, another limitation of the study is the participants who were participating in the teaching experience for the first time. In further studies, longitudinal studies will be helpful to understand the teacher identity formation in the process.

\section{References}

Baran, E., Çilsalar, H., and Mesutoğlu, C. (2017). Investigating the preservice teachers' knowledge sources for classroom management: A case study. Kastamonu Education Journal, 25(1). 155-170

Beauchamp, C., and Thomas, L. (2006, July). Imagination and reflection in teacher education: The development of professional identity from student teaching to beginning practice. In Conference Proceedings from the 4th International Conference on Education and Imagination (pp. 12-15).

Beauchamp, C., and Thomas, L. (2009). Understanding teacher identity: An overview of issues in the literature and implications for teacher education. Cambridge Journal of Education, 39(2), 175-189. doi:10.1080/03057640902902252

Beijaard, D., Meijer, P. C., and Verloop, N. (2004). Reconsidering research on teachers' professional identity. Teaching and Teacher Education, 20(2), 107-128. doi:10.1016/j.tate.2003.07.001 Beijaard, D., Verloop, N., and Vermunt, J. D. (2000). Teachers' perceptions of professional identity: An exploratory study from a personal knowledge perspective. Teaching and Teacher Education, 16(7), 749-764. doi:10.1016/S0742-051X(00)00023-8

Börger, H., and Tillema, H. (1993). Transferring knowledge to classroom teaching: Putting knowledge into action. In C. Day, J. Calderhead, and P. Denicolo (Eds.) Research on Teacher Thinking: Understanding Professional Development, (pp. 185-197) Routledge.

Canrinus, E. T., Helms-Lorenz, M., Beijaard, D., Buitink, J., and Hofman, A. (2012). Self-efficacy, job satisfaction, motivation and commitment: Exploring the relationships between indicators of teachers' professional identity. European Journal of Psychology of Education, 27(1), 115-132. doi:10.1007/s10212-011-0069-2

Creswell, J. W. (2009). Research design, qualitative, quantitative, and mixed methods approaches ( $3^{\text {rd }}$ edt). California: SAGE Publications.

Day, C. (2002). Developing teachers: The challenges of lifelong learning. Routledge.

Doppenberg, J. J., den Brok, P. J., and Bakx, A. W. E. A. (2012). Collaborative teacher learning across foci of collaboration: Perceived activities and outcomes. Teachers and Teacher Education, 28, 899-910. doi:10.1016/j.tate.2012.04.007

Duru, S. (2006). The influences on teacher identity and the suggestions for the new teacher identities. Eurasian Journal of Educational Research (EJER), (22), 121-131.

Flores, M. A., and Day, C. (2006). Contexts which shape and reshape new teachers' identities: A multi-perspective study. Teaching and Teacher Education, 22(2), 219-232. doi:10.1016/j.tate.2005.09.002 
Gee, J. (2000). Identity as an analytic lens for research in education. Review of Research in Education. 25, 99-125. doi:10.2307/1167322

Goodson, I. F. (1981). Life history and the study of schooling. Interchange Ontario Institute for Studies in Education, 11(4), 62-76. doi:10.1007/BF01810006

Kelchtermans, G. (2009). Who I am in how I teach is the message: Selfunderstanding, vulnerability and reflection? Teachers and Teaching, 15, 257272. doi:10.1080/13540600902875332

Korthagen, F. A. (2004). In search of the essence of a good teacher: Towards a more holistic approach in teacher education. Teaching and Teacher Education, 20(1), 77-97. doi:10.1016/j.tate.2003.10.002

Lamote, C., and Engels, N. (2010). The development of student teachers' professional identity. European Journal of Teacher Education, 33(1), 3-18.

doi:10.1080/02619760903457735 Levine, A. H., and Marcus, A. S. (2010). How the structure and focus of teachers' collaborative activities facilitate and constrain teacher learning. Teaching and Teacher Education, 26, 389-398. doi:10.1016/j.tate.2009.03.001

Mayer, D. (1999). Building teaching identities: Implications for preservice teacher education. Paper presented at the Australian Association for Research in Education and New Zealand Association for Research in Education Conference, Melbourne, Australia, 29 November-2 December 1999. https:// www.aare.edu.au/data/publications/1999/may99385.pdf

Neuendorf, K. A. (2002). The content analysis guidebook. Thousand Oaks, CA: Sage.

Olsen, B. (2008). How reasons for entry into the profession illuminate teacher identity development. Teacher Education Quarterly, 35(3), 23-40.

Rodgers, C. R., and Scott , K. H. (2008). The development of the personal self and professional identity in learning to teach. In Marilyn Cochran-Smith, Sharon Feiman-Nemser, D. John McIntyre and Kelly E. Demers Lincoln (Edts). Handbook of Research on Teacher Education, Routledge Handbooks Online. https://www.routledgehandbooks.com/doi/10.4324/ 9780203938690.ch40

Sachs, J. (2005). Teacher education and the development of professional identity: Learning to be a teacher. Denicolo, P. and Kompf , M. (Edts). Connecting policy and practice: Challenges for teaching and learning in schools and universities, pp. 521. Oxford: Routledge. https://www.taylorfrancis.com/books/9780203012529

Schlee, R. P., and Van Duzer, J. B. (2007). An examination of alternative approaches to the treatment of confidential information in live case projects. Marketing Education Review, 17(2), 71-82. doi:10.1080/10528008.2007.11489006 Shulman, L. S. (1986). Those who understand: Knowledge growth in teaching. Educational Researcher, 15(2), 4-14. doi:10.3102/ 0013189X015002004

Stronge, J. H. (2018). Qualities of effective teachers. ASCD.

Teven, J. J., and McCroskey, J. C. (1997). The relationship of perceived teacher caring with student learning and teacher evaluation. Communication Education, 46(1), 1-9. doi:10.1080/03634529709379069

Thomas, L., and Beauchamp, C. (2007). Learning to live well as teachers in a changing world: Insights into developing a professional identity in teacher education. The Journal of Educational Thought, 41(3), 229. doi:10.11575/jet.v41i3.52496 
Tsang, K. K., and Jiang, L. (2018). Positive emotional experiences in teaching, teacher identity, and student behaviors: A symbolic interactionist perspective. Schools, 15(2), 228-246. doi:10.1086/699890

Van der Heijden, H. R. M. A., Geldens, J. J. M., Beijaard, D., and Popeijus, H. L. (2015). Characteristics of teachers as change agents. Teachers and Teaching: Theory and Practice, 21(6), 681-199. doi:10.1080/13540602.2015.1044328

Van Veen, K., and Sleegers, P. (2006). How does it feel? Teachers' emotions in a context of change. Journal of Curriculum studies, 38(1), 85-111. doi:10.1080/00220270 500109304

Volkmann, M. J., and Anderson, M. A. (1998). Creating professional identity: Dilemmas and metaphors of a first-year chemistry teacher. Science Education, 82(3), 293-310.doi:10.1002/(SICI)1098237X(199806)82:3\%3C293::AIDSCE1\%3E3.0.CO;2-7

Walkington, J. (2005). Becoming a teacher: Encouraging development of teacher identity through reflective practice. Asia-Pacific Journal Of Teacher Education, 33(1), 53-64. doi:10.1080/1359866052000341124

Yasar, M., Karabay, A., and Bilaloglu, R. (2013). “Have I become a teacher?” The perspectives of pre-service teachers about factors that are effective on the formation of the teacher identity. Turkish Studies, 8(7), 269-282. doi:10.7827/ TurkishStudies.5337

Yıldırım, A., and Şimşek, H. (2008). Qualitative Data Analysis in Social Sciences. Ankara: Seçkin Publication.

Zembylas, M. (2003). Emotions and teacher identity: A post structural perspective. Teachers and Teaching, 9(3), 213-238. doi:10.1080/13540600309378

Zembylas, M. (2005). Discursive practices, genealogies, and emotional rules: A poststructuralist view on emotion and identity in teaching. Teaching and Teacher Education, 21(8), 935-948. doi:10.1016/j.tate.2005.06.005

\section{Araştırmanın Etik Izinleri}

Yapılan bu çalışmada "Yükseköğretim Kurumları Bilimsel Araştırma ve Yayın Etiği Yönergesi" kapsamında uyulması belirtilen tüm kurallara uyulmuştur. Yönergenin ikinci bölümü olan "Bilimsel Araştırma ve Yayın Etiğine Aykırı Eylemler" başlığı altında belirtilen eylemlerden hiçbiri gerçekleştirilmemiştir.

Etik kurul izin bilgileri

Etik değerlendirmeyi yapan kurul ad1 $=$ Yozgat Bozok Üniversitesi

Etik değerlendirme kararının tarihi=21.08.2017

Etik değerlendirme belgesi sayı numarası= 95799348-044-E.9714

\section{Authors' Biodata / Yazar Bilgileri}

Hatice Çilsalar Sagnak works as a Asist. Prof. Dr. at Yozgat Bozok University, Faculty of Education, Department of Curriculum and Instruction.

Hatice ÇİLSALAR SAGNAK Yozgat Bozok Üniversitesi Eğitim Programları ve Öğretim Anabilim dalında Dr. Öğr. Üyesi olarak görev yapmaktadır.

Gökçe Sancak Aydin works as a Asist. Prof. Dr. at Yozgat Bozok University, Faculty of Education, Department of Guidance and Psychological. 
Gökçe SANCAK AYDIN Yozgat Bozok Üniversitesi Rehberlik ve Psikolojik Danışmanlık Anabilim dalında Dr. Öğr. Üyesi olarak görev yapmaktadır. 